NBER WORKING PAPER SERIES

AMNESTY, ENFORCEMENT AND TAX POLICY

Herman B. Leonard

Richard J. Zeckhauser

Working Paper No. 2096

NATIONAL BUREAU OF ECONOMIC RESEARCH 1050 Massachusetts Avenue

Cambridge, MA 02138

December 1986

The research reported here is part of the NBER's research program in Taxation. Any opinions expressed are those of the authors and not those of the National Bureau of Economic Research. 
NBER Working Paper \#2096

December 1986

Amnesty, Enforcement and Tax Policy

ABSTRACT

Amnesties are widely used in society to rehabilitate past sinners, to collect resources, such as library books, that would otherwise be unrecoverable, and to make enforcement easier by reducing the ranks of delinquents. Over the past four years, tax amnesties have emerged as a major instrument of state revenue policy. Twenty states conducted amnesties. Record collections were made by New York (\$360 million) and Illinois (income tax amnesty dollars 3.48 of collections). Amnesties took in dollars that would probably have escaped otherwise, and tax rolls were bolstered. Tax amnesties also have costs, however. They may anger honest taxpayers, diminish the legitimacy of the tax system by pardoning past evasion, and decrease compliance by making future annesties seem more likely.

Should the federal government, aswirl in tax reform and suffering from an estimated $\$ 100$ billion tax evasion problem, now offer an amnesty of its own? What type of federal program would most likely be offered? What would it be likely to accomplish? state tax annesties have generally been coupled with enhanced enforcement efforts, a feature intended to preserve the legitimacy of the tax system. The amnesty/enforcement combination twists the penalty schedule, lowering it now raising it later, in that way encouraging prompt payment. With no past sins to hide, future compliance also becomes less costly, hence more probable. Any federal amnesty, we predict, would be accompanied by a strengthening of enforcement. After reviewing the state experience, we speculatively estimate that a federal amnesty/enforcement program wight collect $\$ 10$ billion initially and yield a continuing increment to annual revenues on the order of $\$ 10$ billion.

Herman B. Leonard

Kennedy School of Government

Harvard University

79 John F. Kennedy street

Cambridge, MA 02138
Richard J. Zeckhauser

Kennedy School of Government Harvard University 79 John F. Kennedy Street Cambridge, MA 02138 


\section{AMNESTY, ENFORCEMENT AND TAX POLICY}

by

Herman B. Leonard and

Richard J. Zeckhauser*

Massachusetts raised $\$ 85$ million through a tax amnesty program; New York collected more than four times that amount. In California, Illinois, Alabama, Arizona, Wisconsin, and twelve other states, people and corporations willingly stood in line for hours to pay the taxes they owed while delinquency penalties were temporarily suspended, to deliver bills and checks and coins to state treasuries. Many were choosing to make a first appearance on the tax rolls.

Tax amnesties have raised hundreds of millions of dollars that revenue collectors would otherwise have found difficult or impossible to capture. Amnesties have swelled the rolls of paid-up taxpayers and increased the population of regular filers. State revenue department estimates suggest that a well-publicized amnesty combined with stricter future enforcement considerably increases the level of future voluntary compliance with tax laws. Amnesties may have had some less positive effects as well. They may have angered law-abiding taxpayers who dislike seeing tax breaks given to abusers of the system. Current amnesties may have encouraged some citizens to believe that there will be future amnesties as well, reducing their incentives to keep current on their payments. Not surprisingly, considerable controversy has arisen over whether (and how) tax policy should make use of amnesty programs. In practice, tax amnesties have been coupled with enhanced enforcement efforts, a feature that seems essential to preserve the legitimacy of the tax 
code. (Moreover, given some factions' opposition to any reductions of penalties, the promise of more vigorous enforcement is probably necessary to win political approval of an amnesty program.) An amnesty and enforcement program twists the schedule of expected tax penalties, lowering them temporarily but raising them later, thus providing a strong incentive for offenders to come forward. An important further effect is to make future compliance more attractive. Citizens who have past delinquencies to conceal may hesitate to file an accurate current return lest it raise questions about previous years. But once the slate has been wiped clean under an amnesty program, their cost of future compliance is reduced.

Should the federal government follow the example of the states and offer a tax amnesty of its own? Today, when unprecedented federal budget deficits have reached 5 percent of gross national product (GNP), and many believe that tax evasion is costing the government as much as $\$ 100$ billion a year, this question seems increasingly worthy of attention. Barring massive increases in enforcement expenditures, an amnesty might be the only way to bring many evaders back into compliance. Congress's recent approval of a sweeping tax reform, designed in part to restore legitimacy to the tax code, provides an opportune time to consider a federal tax amnesty coupled with more vigorous enforcement to capitalize on and help mark a new regime.

Some observers have argued that the decision whether to offer an amnesty should be based on a fairly mechanical weighing of additional tax collections to be achieved now against possible losses later. Such an approach, which in effect considers an amnesty program purely as a revenue-raising device, would be most appropriate if the program could be expected to raise a significant 
fraction of tax revenues, say 3 or 4 percent of total collections. Existing estimates, none of which claims to be more than speculation, are less optimistic. Allen H. Lerman, of the Office of Tax Analysis, U.S. Department of Treasury, suggests that an amnesty might raise \$1 billion (not including revenue due to greater future enforcement). Our assessment suggests that a combined amnesty/enforcement program -- which political forces may make an inevitable coupling -- could raise as much as $\$ 10$ billion over the status quo, but even that sum would be only about 1.5 percent of revenues. To judge the virtues of an amnesty, policy makers will have to weigh the revenues raised against its other consequences, both positive and negative, which may be substantial. For example, some elements of a tax amnesty will support, and other elements will undermine, the legitimacy of the tax system, and therefore the revenues that it collects. Given the salience of taxes in the citizen's interactions with the government, a tax amnesty may also affect the perceived overall legitinacy of government.

Many state amnesties have been accompanied by a significant strengthening of enforcement efforts. The revenues thus generated must be viewed as a product of the joint instrument. How then should we assess the efficacy of a prospective federal amnesty? Should we consider merely the effects of adding an amnesty, leaving present enforcement efforts unchanged? Or should we compare the status quo with an amnesty program that also includes a stepped-up enforcement program? Or should we assume a strict enforcement program and see what an amnesty adds?

In our view, an amnesty is a political instrument -- a compromising counterbalance that helps lead to stricter enforcement efforts. (Indeed, 
Congress may never find time for a consequential discussion of enforcement except in the context of debate over a federal amnesty.) Thus a federal amnesty, together with the enforcement efforts likely to accompany. it, should be judged against the realistic alternative, the enforcement expected without an amnesty. Moreover, to assess the full effects of an amnesty on revenue, we must consider the future impact of the accompanying enforcement changes. The experience of the states, as we shall see below, suggests that enhanced future revenues exceed the direct revenues of the amnesty itself. Any revenue projections must remain highly speculative, however, making it a11 the more important to examine the other consequences of a potential amnesty.

\section{When Do We Give Amnesty?}

To help focus our thoughts about tax amnesties, we believe it is useful to consider the justifications for other kinds of amnesty. When have societies given amnesties? What characteristics do amnesties share? What purposes are they alleged to serve, and what do they actually accomplish? When are they socially productive? Having explored these issues, we shall return to the special case of tax amnesties.

Amnesties are not unusua1. In the past two decades, governments in the United States have given amnesties for draft evasion, parking tickets, unreturned library books, and now tax evasion. Perhaps the most significant amnesty was signed into law this fal1; it offers permanent residence status to an estimated 4 million illegal aliens who entered the United States before January 1982. In conjunction with the amnesty, substantial penalties will be 


$$
-5-
$$

imposed on employers of ineligible and future illegal aliens, with a promised increase in enforcement efforts. This amnesty eases the transition to a new regime, in part by exempting old offenders, whose sheer numbers would make strict enforcement impossible. It also reflects a political compromise between defenders of present illegal residents (amnesty supporters) and the interests seeking to stem the illegal tide, who gain significant sanctions for new offenses.

It is common -- though not universal -- for the winners of a war to provide some form of amnesty for those who honestly supported and honorably defended the losing side. Many societies give continuing amnesties for some offenses. Statutes of limitations erase liability for torts, for prosecution for misdemeanors and most felonies (but not federal tax fraud!); large library fines are often imposed, but seem almost never to be collected. Some amnesties are forma 1 and require an application process and documentation; others are unadvertised. 1 For example, most revenue collectors waive some penalties for taxpayers who claim administrative error as a cause of their noncompliance with tax laws and who voluntarily appear to pay the tax and any interest due.

Other social conventions akin to amnesty are also common. The enforcement of some laws is so casual as to constitute a practical amnesty. Drivers in large packs of automobiles traveling a few miles per hour over the speed limit are virtualiy immune from speeding tickets; citizens are so unlikely to be penalized for keeping small amounts of marijuana for private use in their homes that society might as well have declared an amnesty; ancient laws about sexual practices are routinely ignored and largely 
unenforced. Lax enforcement sometimes reflects simple priority setting. Some laws are viewed as obsolete, given changing social norms, and we naturally direct scarce enforcement resources toward more important offenses. But other choices are unrelated to the seriousness of the crimes. Low-level street crime in some communities enjoys something like continuing amnesty because jails are overcrowded; enforcement authorities, aware that penalties are being waived for most convictions, direct their attention and arrests toward offenders who can successfully compete for space in jail.

For many violations, however, societies never give amnesties, and virtually never even give pardons. For heinous crimes, major frauds like embezzlement, or desertion from a combat unit under fire, no serious consideration is given to blanket abatements of penalties (though in carefully reviewed cases with extenuating circumstances, an individual offender may be shown leniency).

In what circumstances are amnesties particularly likely? First, societies generally give amnesties for offenses committed by a relatively large number of otherwise reasonably ordinary citizens, whose allegiance and noncriminal reputations we wish to maintain or reclaim. A classic example is draft evasion in a war that is unpopular or widely perceived as unjust. Many young men evaded the draft in the Vietnam era. Though by no means a random sample of draft-age citizens, they were not significantly set apart from other citizens except as a result of evading the draft. Similarly, people with many parking tickets are difficult to distinguish from the rest of us. 2 when a law is sufficiently flouted, it becomes illegitimate. In some cases, we modify the law. But when, as with taxes and illegal aliens, changing the law is 
particularly undesirable -- we need government revenues and we will not throw open our doors to immigrants -- amnesty may provide a way to recapture legitimacy.

Second, societies are more likely to give amnesties for an of fense that did not directly damage an identified party. Contrast draft evasion with desertion under fire. Draft evasion certainly affects other people -- someone else will be forced to serve -- but it is hard to know exactly whom. 3 Desertion from a combat unit under fire, in sharp contrast, directly endangers the lives of an identified group of individuals, and is therefore harder to forgive.

Third, we are more likely to declare an amnesty for a violation that is unrelated to other offenses. Society is more likely to provide amnesty for private home use of small amounts of marijuana than for assault, theft, or burglary. Smoking marijuana at home -- at least under current social mores -- is not a very strong indication of sociopathic behavior. Being involved in street crime is more strongly linked to a pattern society wants to discourage.

Fourth, amnesties seem to be more likely when society will find it difficult to enforce the penalty anyway. Forgiving library fines is a good way to recover books, particularly when the alternative is to have neither the books nor the fines. Proponents of amnesty for illegal aliens argue that it would be too costly and too painful to find and deport the multitude who established residence in the United States some years ago, and that society might as well declare this reality to be in conformance with the law. Society gains by eliminating the deadweight loss (of books not available at the library and of residents who must avoid contact with public agencies) and by 
bringing the violators into conformance with social norms when there is little to gain by keeping them estranged.

\section{Benefits and Costs of Amnesties}

What do societies seek to gain by offering amnesties? Common1y, there are seven main benefits. First, an amnesty may enable us to collect some proportion of past debts that otherwise would be uncollectable. In 1983, for example, Philadelphia collected over 160,000 volumes during its highly publicized one-week library amnesty -- books that would otherwise have been lost to $i$ ts system. (That event apparently provoked much mutual congratulation and removed a load of guilt from 35,000 patrons, whom the library praised as showing "great respect for reading and libraries.") Parking and tax amnesties do not eliminate the original charges, just the supplementary penalties. In effect delinquents are offered a chance to clear the slate by paying some of what they owe. Illegal aliens eligible for permanent residence under our new legislation will be allowed eighteen months to get on the books, become taxpayers, and so on. Failing this, they will be liable to expulsion.

Second, amnesties encourage renewed compliance. After a parking amnesty, people may take more care to park legally. This benefit is particularly large when, in the absence of an amnesty, there is a strong incentive for delinquents to remain so. A draft evader who wanted to return from Canada and go straight in 1972 no longer faced Vietnam but Leavenworth. Tax evaders, to hide past delinquency, often must continue to cheat. A bank cannot advance further credit to a corporation (or country) in default, even if the new loan 
is expected to be profitable. ${ }^{4}$ Amnesties allow society to rearrange incentives that otherwise favor continued noncompliance on the part of a de 1 inquent.

Third, giving an amnesty often makes the society better able to control the future. The conquering army that offers amnesty to its vanquished opponents if they surrender the ir arms -- and threatens powerful action against those who do not cooperate by a given date -- not only begins to heal society's wounds but dramatically reduces the potential for future armed conflict. (The military analogy seems appropriate in judging the tax amnesty of our home state of Massachusetts.) Parking ticket amnesties result in a current address list useful in future collection efforts, thus making future compliance more likely. An amnesty for toxic waste dumps might permit society to find out where they are before poisons filter into groundwater. And a tax amnesty makes future adherence to the tax code more likely, by removing the need to conceal past sins. An amnesty is desirable if it lowers the cost of behaving well in the future.

Fourth, amnesties allow society to forgive violators who are unlikely to become repeat offenders, penitents, individuals who have become delinquent by blunder, or offenders who have transgressed some rule society regards as minor. Some violations may have sprung from well-intentioned behavior. For example, many of those who evaded the Vietnam draft did so out of honest disagreement with their government; they can claim a loyalty to principles that society strongly supports. Although society cannot affirm their decision to evade, it may want to mitigate the penalty; amnesty after the war provides one avenue. 
Fifth, amnesties help to reduce or eliminate deadweight burdens from a social schism or from individual guilt. The threat of punishment may deter an offense, but once deterrence has failed, the continuing guilt or ostracism serves little purpose. Punishment may deter future offenses, but it cannot change what is already done. Once the desire for retribution or revenge has been long enough served, the time may come to bury the hatchet to reduce the implied waste.

Sixth, amnesties may permit society to declare that it made a mistake and now wants to change its mind. Some believe that the vietnam draft amnesty is at least ambiguous in this respect -- and, therefore, perhaps particularly dangerous. Establishing that society can change its mind may make many kinds of socially undesirable behavior more attractive, undercutting social norms. Some observers might interpret an amnesty for past marijuana offenses as a sign that an amnesty for cocaine will eventually be offered. 5

Finally, amnesties can make the transition to a new enforcement regime seem more fair. When society systematically fails to enforce a law over a long period, it implicitly creates a presumption that the offense is not serious, encouraging otherwise honorable members of society to choose noncompliance. Surveys suggest that as many as one-third of Americans think that tax cheating can be condoned. Under such circumstances, it may seem unfair to change the degree of enforcement, subjecting those who offended under a known lax enforcement regime to penalties consistent with a harsher view of the offense. 6

Even for offenses regarded as serious, a long-standing failure to identify and punish perpetrators may reduce the legitimacy of a later roundup. 
As we debate how to improve enforcement of immigration laws -- sending the message that illegal residence (or employing illegal aliens) is a serious offense -- we also consider amnesty for those who have been in residence long enough. After so many years of ineffective action, it seems unfair to enforce the law on those individuals now. Due process requires fair warning.7 And for those who object that amnesty reduces the legitimacy of the original system, the promise of stricter enforcement in the future may be an adequate compensation. Both softies and disciplinarians may prefer a system with reduced penalties now and stiffer penalties later to the status quo.

Amnesties clearly have costs as well as benefits. First, they of ten annoy nondelinquents. One of the present authors usually obeys speed limits and thinks speeders should be ticketed; the other would like to drive faster and feels like a chump because those who are driving faster are not being arrested. Neither of us particularly likes the quasi-amnesty we observe.

Second, amnesties may have undesirable incentive effects. Will those subject to the next military conscription remember that Vietnam draft evaders were eventually given amnesty? Will that knowledge inappropriately tilt their choices in a socially undesirable direction? Why pay parking tickets now if there will be an amnesty later? Why return any library book now if you can keep it free until the next amnesty?

To minimize these incentive effects, many amnesties are declared to be on a "one-time-only" basis. If an amnesty is believed to be truly unique, it affects only past actions, which cannot be changed, and should have no impact on future decisions. But it may be hard to make a firm commitment never to have another amnesty. If it made sense once, why will it not make sense 
again? Moreover, many amnesties are clearly foreseeable. The United States has given amnesties for draft evasion after each war; library amnesties are given with regularity. ${ }^{8}$ In these instances, the bad incentive effects of an amnesty were evidently thought to be outweighed by the benefits of drawing society back together. 9

Amnesties have another potentially critical disadvantage: they undermine the strength of the social sanction against the amnestied behavior, reducing the guilt felt by delinquents when they misbehave. Guilt, or its cousin shame, is a highly efficient tool for social control. It is imposed automatically, with certainty, for any misbehavior by anyone with a conscience. And it works. Most people have many chances to steal with virtually no chance of being caught, yet few do so. Societies therefore expend great effort to instill the values that create conscience.

Even vigorous enforcement efforts can detect only a small fraction of offenders. If we must rely on citizens' desire to avoid imposed penalties (rather than shared values) to ensure compliance with the law, penalties must be large enough to balance out the low probability of apprehension. In fact, we may be reluctant actually to impose such severe punishment. 10

As guilt -- or, to put it positively, the warm feeling that comes from being diligent and honest -- diminishes as a force in the compliance decision, society must rely on the considerably more expensive and less efficient approach of identifying and punishing delinquents--both tasks that must be conducted under strict rules protecting citizens' (and convicts') rights. If amnesties significantly reduce the guilt associated with future noncompliance, they may be a bad bargain indeed.11 


\section{Benefits and Costs of Tax Amnesties}

In several respects, tax evasion is the kind of offense for which amnesty is relatively likely -- or at least plausible. No doubt some people became tax delinquents by mistake and would now like to become honest citizens but are deterred by the expense or embarrassment. A significant proportion of taxes is evaded -- nearly 20 percent at the federal level, it is estimated. Tax evasion by one person does not directly harm other identifiable individuals. Most past tax evasion will be difficult to detect if it has not already been identified, so a tax amnesty is making official what is highly probable anyway.

Moreover, tax amnesties may provide the benefits of ten sought from amnesties in other areas. They reduce guilt of evaders (many of them otherwise ordinary citizens) -- a deadweight loss that hurts them without helping anyone else. They provide direct benefits in the form of voluntary back tax payments. They help to reduce future noncompliance by adding former delinquents to the tax rolls and removing the danger that past malfeasance will be revealed. And, perhaps most important, amnesties smooth the transition to a new harsher regime of tax law enforcement with fair warning.

But tax amnesties may also share the disadvantages of other amnesty programs. Ordinary citizens who have been paying their taxes may feel unjustly treated either because they are denied vengeance or because they are made to feel like chumps. Moreover, depending on the form of amnesty granted and the perceived likelihood of repetition; tax amnesties might encourage evasion, allowing delinquents to hope they may later be able to reconsider 
freely.

Many amnesties relate to single or sporadic offenses, such as a student occupation of a college building, the possession of handguns when they are declared illegal, or draft evasion during the Vietnam War. Our tax program, by contrast, will continue indefinitely, and chiselers and cheaters will always be among us. In this respect tax amnesties resemble programs offering permanent residence status for long-time illegal aliens or parking ticket amnesties. The amnesty must be viewed in terms of long-term objectives of securing future compliance -- for example, deterring new illegal aliens by making them unemployable. That is why tax amnesties, and our nation's new immigration amnesty, are linked with stiff enforcement programs for the future. We are trying not only to bring past violators back into the fold as full-fledged citizens (a principal objective of the Vietnam draft amnesty), but also to prevent strays in the future.

Finally, and perhaps most importantly, amnesty for tax evasion may make cheating seem less significant, reducing the guilt felt by those who consider stretching their deductions or underreporting their income. A substantial fraction of taxpayers may behave honestly because they (probably incorrectly) believe cheating is likely to be detected, but many others probably comply because they believe it is the right thing to do.12 If amnesties make evasion seem forgivable and thus insignificant, they may have serious financial consequences in reducing voluntary compliance over the long run. In addition to equity losses, this will mean higher and therefore less efficient tax rates.

The continuing nature of our tax collection system is a critical feature 
distinguishing tax amnesty from, for example, a draft-evaders amnesty for a particular war (which merely reduces penalties). A tax amnesty is almost inevitably coupled with increased penalties and enforcement efforts. The penalty schedule is twisted -- not necessarily lowered. If strong sanctions are prerequisites for maintenance of guilt and conscience (and possible ostracism for offenders), then a tax amnesty could actually be part of a guilt-strengthening effort.

\section{Tax Amnesty in Practice: The Massachusetts Experience}

Nineteen states have conducted explicit tax amnesties in the last three years, collecting about $\$ 1$ billion in what they consider otherwise largely uncollectible taxes from over 500,000 taxpayers. Three states are currently in the midst of amnesty periods; two others have legislative authorization to begin amnesties soon. The programs have generally involved forgiveness of criminal and civil penalties for those who came forward to declare their delinquency and pay the tax they owed, together with a (possibly substantial) interest charge for the "loan" they had obtained by not paying earlier. Those whom the state has already informed of a suspected delinquency are often excluded or given only partial amnesty.

The highly publicized Massachusetts program, which became something of an archetype, ran from October 17, 1983, to January 17, 1984. Its avowed purpose was to collect revenue immediately, to permit transition to a new regime of considerably tougher enforcement, and to increase voluntary compliance in the future by getting current delinquents onto the tax rolls and encouraging them 
to stay there. The program was, on its own terms, wildly successful. Even the most optimistic forecasters within the Department of Revenue had guessed that the immediate payments from amnestied taxpayers would not exceed $\$ 20$ million. When the dust settled and the 52,000 amnesty applications were tallied, the state had collected $\$ 85$ million, at a cost of only $\$ 2$ million for extra staff and other direct program expenditures. Amnesty payments were received for every major tax the state imposes, though delinquencies related to personal and corporate income taxes generated well over half of the payments. Over 60 percent of the payments were from taxpayers who had not previously filed any information about the tax they came forward to pay. Among income tax delinquents, about half of the delinquencies were for a single year, but over 20 percent were for four. years or more.

The Massachusetts amnesty was combined with a heightened emphas is on enforcement. The amnesty period was preceded by a series of dramatic enforcement actions, including highly publicized seizures of assets from taxpayers the state claimed were delinquent. New legislation (which included the authorization for amnesty) had recently stiffened the penalties for evasion, permitted felony prosecution for some particularly flagrant evaders, allowed the Commonwealth to revoke the licenses of or cancel contracts with delinquents, and provided additional staff and enforcement resources (including new funds for computers to track delinquents more reliably). In this context, which presumably heightened the anxiety of delinquents, the temporary amnesty period, announced with only one day of public warning, was presented as a never-to-be-repeated chance to get on the right side of the law. The enforcement agencies had been displaying their new, sharper teeth. 
Many Massachusetts tax delinquents probably had believed that the Commonwealth would never get serious about tracking them down and collecting unpaid taxes and penalties. Now suddenly things looked different. Assets were seized, restaurants closed, hotels shut down. Tax evaders faced felony prosecution, and it seemed as if some would actually go to jail. A surprising number of delinquents seized the opportunity offered by amnesty to pay up and stop worrying about how much bite might be behind the bark.

But the direct payments made under the amnesty program were only one class of benefit. The program also played an important role helping Massachusetts move to a new period of stiffer enforcement without seeming to break an implicit contract with taxpayers about how much enforcement scrutiny there would be. Since concentrating the new enforcement resources on prior delinquents was likely to be procedurally difficult and conceivably to appear unjust, and since only a small percentage of past delinquents was likely to be discovered, there was little reason to try to clear out the inventory of delinquents through direct enforcement. Why not declare an amnesty and let them pay up on their own, particularly since this approach would probably yield more money? ${ }^{13}$ An individual who failed to come forward despite the amnesty program would then seem fairer game for a stern penalty program. Using an amnesty to smooth the rough edge of the transition also struck a useful political compromise between self-avowed softies and hard-liners.

The new enforcement regime is expected to have two major benefits: (1) the state may be able to increase its collections from future delinquents substantially; (2) future voluntary compliance with the tax code may be increased. Massachusetts has estimated both of these effects and claims they 
are large in comparison with the direct returns of amnesty. According to Department of Revenue figures, audit assessments pursuant to the new enforcement efforts in fiscal years 1983 through 1985 exceeded those of the prior three-year period by $\$ 263$ million. Total collections of delinquent taxes (excluding receipts under amnesty) were up $\$ 130 \mathrm{million}$ over the same period. And, from a comparison of econometric estimates of tax revenues (based on preamnesty behavior) with actual collections in fiscal years 1984 and 1985, the Commonwealth estimates that improvements in voluntary compliance have resulted in $\$ 480 \mathrm{million}$ in extra tax payments across the two-year period (excluding the direct collections from amnesty).14

Since it is impossible to know exactly what level of tax payments would have prevailed in the absence of tougher enforcement and amnesty, these estimates must be viewed with caution. They do suggest, however, that the continuing payoffs from more vigorous enforcement -- greater delinquent tax collection and more voluntary compliance -- substantially exceed the direct revenues from the amnesty.

A few figures will put the gains from amnesty in perspective. Massachusetts' revenues in fiscal year 1984 were $\$ 5.8$ billion. Direct amnesty revenues (from an expressly one-time initiative) were $\$ 85$ million, or 1.5 percent of annual revenues. A generous estimate would put the measurable impact of the amnesty and enforcement program at roughly $\$ 400$ million per year, or about a 6 percent increase in annual revenues. If there is greater voluntary compliance now, there will be less delinquent tax to find and assess later, which suggests that straight extrapolations based on short-term state experiences would be generous indeed. But even if we cut these figures by 
two-thirds and consider a 2 percent increase in the permanent level of annual revenues, the impact is still far more important than a one-time collection of 1 or 2 percent of revenues. The revenue effectiveness of an amnesty and enforcement initiative depends primarily on the extent to which it shifts collections permanently upward, not how much it yields on a one-time basis.

\section{The Effects of State Tax Amnesties}

The roots of state tax amnesty programs are obscure. Illinois sponsored a small program in 1982 , raising less than $\$ 100,000$ in amnesty collections. Large-scale programs began in 1983, when four states ran official tax amnesty programs. Of these, only Arizona collected more than \$1 million or more than 0.05 percent of state tax revenues; its collections were nearly 0.3 percent of state tax revenues for the year. Seven states fielded programs in 1984 -programs straddling year-end are classified under their concluding year -collecting over $\$ 250$ million in total, with two states (Massachusetts and Illinois) collecting $\mathbf{1 . 5}$ percent or more of state tax collections in that year through amnesty payments. The following year saw a large program in California, which raised nearly $\$ 150$ million, about 0.5 percent of tax revenue. Several smaller states had moderate-sized amnesty programs. There has been strong continuing interest in 1986, with New York collecting $\$ 360$ million and Michigan $\$ 103$ million (about 1.7 percent and 1.1 percent of annual revenues, respectively). Table 1 summarizes the states' experience, showing the level of direct tax amnesty collections both in dollars and as a fraction of state tax revenues. 
Have amnesty programs affected compliance? Any analysis must deal with worlds that never existed, since there is no control group of states that have significantly bolstered enforcement without offering amnesty, or offered amnesties without an increase in stringency. Thus we have no way to know whether the Massachusetts program of tougher enforcement would have been socially palatable and politically feasible, and worked equally as well, in the absence of an amnesty. We can, however, observe the growth of state tax revenues in states with and without amnesties. Table 2 shows the difference between the annual growth rate of tax revenues in states with tax amnesties in 1984 and 1985 and in states that had no tax amnesty. As the first column indicates, tax revenues grew more slowly from 1980 to 1983 in states that later had tax amnesties than in states that did not.15 If all states that had tax amnesties in 1984 and 1985 are included, their tax revenues grew about one percentage point slower than other states in the period from 1980 to 1983. But from 1983 to 1985 , when we would expect to see the effects of their tax amnesties, these states' revenues grew faster than those of the other states, by approximately one-half percentage point. Thus, relative to states without amnesties, the annual growth rate of tax revenues in amnesty states shifted up by about one and one-half percentage points during the period in which the amnesties operated. (If the amnesty monies were nonrecurring, states running successful amnesties in 1984 would show no exceptional increase in growth rates from 1983 to 1985.$)$

These results become stronger if we focus on states with particularly large tax amnesty programs. As Table 2 indicates, in states with amnesties collecting over 0.3 percent of state tax revenues, the annual growth rate of 
tax revenues shifted up by 3.5 percentage points as compared with nonamnesty states during the period of the amnesties, with slightly larger shifts if the threshold is raised to 0.5 percent or to 1 percent of tax revenues.

Looking solely at states with amnesties in 1984 provides some evidence that the revenue growth effect persists beyond the year in which amnesty operates. Table 3 shows the tax revenue growth rates between 1982 and 1985 for 1984 amnesty states; for the subset of 1984 amnesty states with amnesty collections of more than 0.3 percent of 1984 tax revenue; and for other states. In the period before amnesty took effect (1982 to 1983), tax revenues in the 1984 amnesty states grew more slowly than in other states, by three to four percentage points. During the actual operation of the amnesty (1983 to 1984), their revenues grew at a rate closer to that of the other states, but still about two percentage points lower. During the postamnesty period (1984 to 1985), their revenues grew faster than in other states, by one to two percentage points. The shift is more dramatic for states with larger tax amnesties (as measured by the fraction of state tax revenues collected through amnesty payments), presumably because of greater earlier noncompliance or more vigorous gains in enforcement. These results are only suggestive, particularly because fiscal years and calendar years do not match in most states, and in some cases amnesty revenue may be split across two tax years. Nevertheless, these figures suggest that the revenue growth associated with amnesty and its accompanying enforcement persists beyond the period in which amnesty is declared.

There are many differences between the economies and tax systems of amnesty and nonamnesty states, which may explain some of the observed shift in 
tax revenue growth rates. These results must therefore be viewed with caution. Still, it is striking that in the period before they declared their amnesties, the tax revenues of amnesty states were growing more slowly than the national average; after tax amnesty, their revenues grew faster than the national average. If amnesty, with an associated greater enforcement effort, is not the explanation, it is at least strongly correlated with whatever the deeper explanation might be. For states that later had amnesty collections of over 0.3 percent of tax revenues, annual growth in tax revenues in the period before amnesty was about two-thirds of the national average; after amnesty, it was slightly above the national average. (Background figures for these calculations are not presented in the tables.) This is quite a substantial shift; even if it does not persist beyond these two years, it would lift tax revenues in these states by 2 to 10 percent above what would have been expected on the basis of the preamnesty period.

How much additional revenue flowed from these states' amnesty and enforcement programs? To provide a crude measure, we projected what tax revenues in 1984 and 1985 amnesty states might have been in the absence of amnesties if the difference from the national average in their revenue growth rates before amnesty had persisted in 1984 and 1985.16 While the projections for each state are subject to considerable variation, the aggregate estimates provide a speculative basis for assessing the total revenue gain associated with tax amnesty programs.

Using this approach, we estimate aggregate gains between $\$ 3$ billion and $\$ 5$ billion over the 1984-85 period in the tax amnesty states. 17 Their actual revenues in that period were about $\$ 120$ billion, so the extra revenues 
apparently associated with their amnesty programs are about 3 to 5 percent of the revenues collected. 18

\section{Toward a Federal Tax Amnesty Revenue Estimate}

The apparent success of state tax amnesty programs, together with historic federal budget deficits, has prompted a variety of proposals for a tax amnesty program at the federal level. Governors of states with successful experiences have pushed the idea. It has been proposed in various forms in Congress. The President has expressed interest. The commissioner of the Internal Revenue Service (IRS) has adamantly resisted suggestions to pursue the idea, but proponents press on. The sweeping tax reform package, recently signed into law, represents a change in regimes that provides a perfect occasion for amnesty, and its phasing provides a rather broad window of opportunity. A program combining amnesty and stricter subsequent enforcement would be expected to increase voluntary tax compliance. Deficits would be reduced, not by forcibly taxing away hard-earned dollars from reluctant taxpayers, but through voluntary contributions from taxpayers happy to have an opportunity to come clean and go straight. So argue the proponents of a federal tax amnesty.

Can the state experience help us understand what might happen under a federal amnesty? There are difficult hurdles to overcome in applying lessons from the state to the federal level. Knowledgeable commentators have taken several tacks. Allen Lerman of Treasury's Office of Tax Analysis has argued that analysis should be limited to amnesty by itself, not amnesty in 
conjunction with an increase in enforcement effort.19 There are two reasons to adopt this focus. First, it is a relevant question in itself -- we may wel1 wish to know the independent effect of annesty, not just the effect of amnesty combined with additional enforcenent effort, because we, can (and do) operate the two policies separately. Second, we may regard the federal enforcement effort as already adequate, or in any case unlikely to be changed. If so, we again want to focus on amnesty by itself.

Lerman estimates that the one-time revenue gains from federal amnesty per se, net of costs and net of revenues actually captured by enforcenent efforts rather than amnesty, would be about $\$ 1$ billion. He takes several different approaches to the estimate, obtaining roughly the same answer each time. We might, alternatively, try to estimate what a greater enforcement effort would bring in by itself. Many have argued that since federal tax enforcement is better than most states', state amnesty/enforcement packages shed little light on what might be achieved at the federal level. The IRS and analysts at the office of Management and Budget (OMB) have developed estimates showing how much additional revenue might be collected through enhanced federal enforcement effort. 20 These estimates suggest that both the average and the marginal yield from enforcement spending is dramatically greater than $\$ 1$ per dollar spent, and often greater than $\$ 10$ per dollar spent. Thus greater enforcement efforts at the federal level should yield substantial revenues. Moreover, these estimates systematically understate the productivity of more enforcement activity, since they exclude the (possibly quite substantial) impact on voluntary compliance. This suggests that there is good reason and ample room for sharpening the tax collector's teeth, even 
at the federal level.21 If an amnesty would help us to move to more vigorous enforcement, some proponents would view it as worthwhile for that reason alone.

The results presented above do not permit us to separate the effects of enforcement and of amnesty -- indeed, we cannot unequivocally attribute the observed effects to the combination of enforcement and amnesty programs. But, particularly in states with programs that attracted a higher fraction of state tax revenues in amnesty payments, the combined enforcement and amnesty activities tended to be prominent features of the fiscal landscape in the year of amnesty. It seems likely that there is a meaningful relationship between the shifts we observed in state tax revenue growth rates and the launching of dramatic new enforcement efforts and tax amnesty programs. And in states with programs perceived as successful, virtually all participants seem to believe that the combination of enhanced enforcement and amnesty worked a special form of magic.

Suppose, then, that we believe (on the basis of IRS and OMB figures) that there is room to enhance federal enforcement and that we do not wish to separate out the independent effect of amnesty; rather, we want to consider how much the federal government might obtain through a combined enforcement/amnesty program. What might the state experience tell us about the prospects for such a program?

The most obvious problem in applying the state experience at the federal level is that the two tax bases have quite different compositions. Many state amnesty programs seem to have been particularly attractive to sales tax delinquents; the virtual absence of excise taxes at the federal level limits 
the relevance of this part of the state experience. Even if we confine our attention to income taxes, however, state amnesties collected considerable delinquent revenue. Table 4 shows the amnesty collections and the income tax-related portion for the four largest amnesty programs (data on Michigan, the last amnesty program to close, were not available. Amnesty income tax collections as a fraction of annual income tax revenues ranged from just under 1 percent to a bit over 3 percent, with a weighted average of about 2 percent. Since total amnesty collections in these states averaged less than 2 percent of total revenues, income tax collections actually represented a larger proportion of amnesty payments than of tax payments overal1.22 There is no obvious reason to believe that federal revenues are less subject to amnestiable delinquency than state revenues -- at least, not by, virtue of their composition across taxes.

A second problem is that the state data provide no direct evidence about how many federal tax delinquents would take advantage of an amnesty. There are many ways to cheat on state taxes and still stay within bounds on federal tax impositions. An obvious example is the taxpayer who files federal forms accurately but falsely claims residence in a low-tax state. He or she has much to tell the state tax collector but nothing to confess to a federal tax examiner. In fact, many of the payments collected by state programs were of this general form. Lerman's review of three state amnesties found that well over 90 percent of those who took advantage of the programs had already filed federal forms. 23 By contrast, about 60 percent of those taking advantage of Massachusetts' amnesty had not filed with the state. Only 1 percent were amending previously filed state forms.24 A second example is people who had 
already been caught by federal auditors. They knew that the exchange of information between the IRS and state tax collectors would eventually catch up with them; many of them took advantage of the state amnesties as well.

This interaction of federal and state tax codes, enforcement, and evasion cuts in both directions. How shall we interpret the fact that most of the state amnesty filers were already in compliance on their federal taxes? If it indicates that enforcement is much better at the federal level, so that taxpayers have cheated more on state than on federal taxes, then a federal amnesty will raise less revenue than the state experience would suggest. However, an alternative interpretation might be that state programs, which were offered without federal participation, were spurned by a large group of noncomplying taxpayers who cheat on both federal and state taxes.

Consider the situation of a taxpayer who has failed to report $\$ 2000$ of income on which he or she would have to pay a 5 percent state tax and a 42 percent federal tax. The state offers an amnesty enabling the delinquent to settle up for a small tax payment (and interest). But it is well known that information on amnesty filers will be made available to the IRS. Thus taking advantage of the state amnesty will result in a much larger tax, interest, and penalty liability at the federal level -- with no relief on the penalty part. This cannot have seemed a very attractive bargain. It is no wonder that the overwhelming majority of taxpayers who took advantage of the state programs were those already paying their federal taxes (or those coming forward to pay state levies such as sales tax, where there was no accompanying federal charge).

This argument suggests that state programs, however successful, tapped 
only a portion of the state delinquencies -- those that did not also involve a federal delinquency. For this reason, estimating federal amnesty revenue on the basis of state experience systematically underestimates the federal revenue potential. The more that evaded state taxes are associated with evaded federal taxes, the greater the underestimate is likely to be.

On net, we suspect, these arguments suggest that the state experience will underestimate the potential of a federal tax amnesty. To be sure, most of those who participated in the state programs were not federal tax delinquents, at least not on these monies. However, federal penalties create strong incentives for federal delinquents not to show up at state amnesty offices. Their absence in the data testifies to their presence of mind.

If extrapolating from the state experience provides an underestimate, then an effective enforcement and amnesty program at the federal level could yield quite substantial revenue. The one-time collection -- if greater than $\mathbf{1 . 5}$ percent of income tax revenues, as the collections in the four largest state programs were -- would be on the order of $\$ 10$ billion. If the growth in federal revenues responds as state tax revenues apparently have, an additional increase of 1 or 2 percent of annual revenues, and conceivably much more, may be achievable, producing a continuing flow on the order of $\$ 10$ billion per year. It is true that we might get much of these increases through stiffened enforcement alone, but without an amnesty, a radical change in enforcement procedures seems unlikely. 25

This estimate of the potential revenue from a combined federal amnesty and enforcement program does not seem unreasonable in light of the amount and composition of federal tax noncompliance. In a widely cited report on tax 
compliance published in 1983, the IRS estimated that approximately $\$ 90$ billion in income taxes went unpaid in 1981.26 As Lerman observes, inflation would raise this total, while the reductions in income tax rates and more effective records-matching and other enforcement would reduce it; it seems reasonable to guess that noncompliance is of the same order of magnitude today. A portion of nonpayment -- for example, the $\$ 9$ billion in unpaid taxes on the profits from illegal activity -- is unlikely to be susceptible to either amnesty or enforcement (or both). A substantial component, however, estimated at about \$70 billion in 1981, is from underreporting of income and overstatement of deductions on submitted tax returns. Some of the large accumulated store of such unacknowledged tax debts might well be susceptible to a well-managed federal amnesty combined with vigorous new enforcement. An additional $\$ 3$ billion annually is due from tax returns that were never filed. This form of evasion was a particularly fruitful source of payments during state amnesties. While the federal situation for nonfilers is clearly somewhat different (because federal taxpayers cannot claim that they are filing in another jurisdiction, and therefore that they are not subject to federal taxes), this might still be a source of considerable revenue under a federal amnesty/enforcement package. 27

Our estimates of the potential revenues cover a wide range; they are subject to considerable doubt. The state experience is difficult to read by itself, and it fits the federal situation only loosely. But if these figures are of the right order of magnitude, they strongly suggest that a combined enforcement and amnesty program at the federal level is well worth careful consideration. They also indicate that a federal program is likely to be more 
-- probably much more -- effective if combined with state amnesties.

We argued that the absence of a federal amnesty effectively blocked many taxpayers' access to state amnesty programs, reducing those programs'

effectiveness. The problem is less severe in reverse, because state penalties and taxes due are generally much smaller than the federal liability an amnesty filer would voluntarily be accepting. Still, it may be harder to admit "error" when one jurisdiction is forgiving but another calls you a tax evader (and penalizes you accordingly). There is no obvious reason why states could not be encouraged to facilitate their citizens' access to the federal amnesty by granting a coordinated umbrella amnesty program. (Indeed, Nebraska has already authorized a contingent amnesty program, to take effect only in concert with a federal amnesty.) To discourage free-riding states the federal government might conceivably share information about taxpayers filing under the amnesty program only with states that are participating, or might offer amnesty only in conjunction with a state. Citizen ire might well force states to comply. If a few states held out, the program would not be spoiled, though revenues would be reduced.

Just how a federal program would work -- whether states would coordinate with it, how many taxpayers might accept the offer, what impact it would have on future compliance -- remains in considerable doubt. It seems clear, however, that the upside potential for revenue gains is considerable.28 
7. Explicit Amnesties Within Implicit Amnesties: What Is Really Different?

Society's preference for obtaining confessions rather than convictions generally leads it to offer lower penalties for those who voluntarily admit wrongdoing. There are both moral and strategic reasons for this approach. Thus, an explicit amnesty may be simply a more extreme or better publicized form of a general policy of (partial) forgiveness for the contrite confessed offender. So it is with tax amnesty programs, which generally waive criminal and civil penalties (at least for those who do not already know they are under investigation). But the open secret is that in virtually all jurisdictions criminal penalties and many civil penalties are routinely waived for those who voluntarily disclose and agree to pay tax delinquencies. Except for the most flagrant tax evasions, the outcome of an investigation is some form of confession of error or miscalculation by the delinquent, combined with payment of the back taxes and interest, sometimes including late payment or failure-to-file penalties.

The penalties are low to start with -- at the federal level, a maximum of 25 percent of tax liability for late payment and an additional 5 percent for negligence. But even these penalties may be abated in cases with extenuating circumstances, which means in practice that they are sometimes negotiated in return for resolution by agreement rather than through litigation -- that is, in return for some form of confession. Both state revenue departments and the IRS abate many of the penalties they assess in the ordinary course of their business; last year the IRS waived nearly 40 percent of the penalties its rules imposed, letting over 4 million taxpayers off the hook for nearly $\$ 2$ 
billion in penalties. Since 1978, the IRS has provided abatements to nearly 20 million taxpayers. Commenting on the IRS's practices, Ira Jackson, commissioner of revenue in Massachusetts, observed, "Amnesty merely offers on a wholesale basis what tax partners in big eight accounting firms and every well-informed tax lawyer routinely obtain for their clients on a retail bas is. " 29

This assessment, accountants tell us, may somewhat overstate the case. Most penalties are not abated, though some questionable penalties are waived swiftly as part of deals. Nevertheless, the offer of amnesty bears important similarities to what is generally available to delinquents who come forth voluntarily. Amnesty differs in four ways: (1) the (relatively small) difference in the terms available, (2) publicity, (3) its importance as an element of a political compromise and as a signaling mechanism fostering a change to a new regime of stricter enforcenent, and (4) its inclusion of elements of pardon and redemption.

Which of these features account for the dramatic amnesty collections of the successful states? Surely not the first -- a small change in the terms of the deal cannot explain such a sudden influx to the confessional. The second and third factors are related, for the effect of amnesties seems to lie mainly in the fact that they are publicized (and therefore draw in many more delinquents) and that they permit the curtain to be raised on a new enforcement regime. (The fourth factor is best assessed by psychologists and theologians, not the economist authors.)

While any policy of negotiated penalties creates equity problems -- some know the penalty structure and others do not, and some have better negotiators 
-- it has the virtue of permitting differentiation anong violators. Whatever our reasons for giving annesty, we are presumably more inclined to give it for some offenses than for others. There is no reason why an annesty need be a blanket forgiveness, and state prograns have generally not been.

Amnesties could be selectively defined. If we want to forgive only small errors, a ceiling can be set. If we think the reporting of some forms of income is more subject to error, and others more to abuse, we may selectively permit amnesty for errors in the types of income less often abused. An amnesty can be selective in the kinds of filers it excuses, the kinds of errors it forgives, the period it covers, and so on. The starting point need not be taxes filed before today; two years from now, the federal government could initiate a selective amnesty that would cover all filings under the "old" tax code but none under the new code. A well-designed selective program could retain much of the benefit of a broader, wholesale clearing of the slate accompanied by stiff penalties for those who do not take advantage of society's "generous offer." An amnesty/enforcement package allows society to ask the repentant sheep to step aside from the incorrigible goats -- and it comes with a strong message that the remaining goats will be pursued. Many erstwhile goats may be induced to convert voluntarily to sheephood.

\section{B. Conclusion}

Whatever its ultimate effects, an amnesty may seem to represent a relaxation of tax enforcement efforts. Some observers are concerned that such a program would unacceptably undercut the legitimacy of our tax code and of 
our laws generally. Most citizens seem to pay their taxes primarily as a matter of conscience. If tax amnesties diminish the force of conscience, spreading the message that tax evasion is commonplace and easily forgiven, they may diminish compliance and force society to raise taxes and rely more heavily on less efficient enforcement mechanisms. This is a serious potential liability, which leads to a political prediction: should there be a federal amnesty, it will, like the prominent state amnesties, be linked with a vigorous new enforcement effort. This coupling would reinforce the virtues of strict enforcement. Any punished individuals would have rejected the opportunity to come forth. They could no longer be thought of merely as tax shavers - - they would have voluntarily chosen, in the face of a generous offer of reconciliation, to remain tax cheaters.

The loss of conscience should not be a problem in a well-orchestrated enforcement and tax amnesty program. Publicized seizures, arrests, prosecutions, fines, audits, and notices signal that tax evasion has unfortunate consequences, that it is being taken more seriously, that those who do not comply will be an increasingly small and besieged minority. Amnesty is a way out before the trap springs shut. The penalty scale is twisted, not reduced. Evasion is made no less a crime.

An amnesty may provide a socially valuable opportunity to set things straight, to move to a more desirable equilibrium with more widespread honest citizenship and greater punishment of violators -- that is, with sharper differentiation between those observing and those outside the social compact.

Though it is conceivable that a strict enforcement program might be enacted by itself, the inclusion of an amnesty would offer four advantages. 
First, merely considering the subject would give the issue new prominence, define it in new terms, get it on the policy agenda, and link it to the tax reform. Second, it might help strike a political balance, and foster innovation by making the new outcome appear to be less of a departure from the status quo. Third, the amnesty would represent a way to provide identifiable funds needed for an additional enforcement effort. 30 Fourth, in conjunction with the enforcement program, the amnesty would reconfigure the tax penalty schedule in a manner that would probably increase revenues both in the short run (because of the incentives to pay up) and in the long run (because paying old debts reduces future costs of compliance).

Our view of the world is summarized in the figure on the next page. If these political prognostications are accepted, the relevant comparison when considering an amnesty will be between boxes $A$ and $D$, the status quo and a new regime offering an amnesty coupled with future strict enforcement.

Our review suggests that an effectively managed federal tax amnesty program, in combination with an advertised enhancement of enforcement, might potentially raise significant revenue, perhaps on the order of $\$ 10$ billion, with continuing substantial revenue gains, albeit of highly uncertain magnitude. Although there are no guarantees such a program will work, the crude estimates of potential gains are large enough to warrant a full-fledged consideration of an amnesty program. And since each enforcement dollar yields many dollars in revenue, quite apart from its effects on nurturing compliance, if the discussion of amnesty merely pushes enforcement issues into Congressional debate, it will certainly have been worthwhile. 


\section{Footnotes}

*Both authors are at the John F. Kennedy School of Government, Harvard University and NBER.

The authors are indebted to a great many people for insightful and useful comments they received. We would particularly like to thank Howard Frant, Arthur Gelber, Grady Hedgespeth, Ira Jackson, Nancy Jackson, Robert Landman, Allen Lerman, Larry Summers, and Diane Ukraine. No implied responsibility is transferred with our thanks.

1. In Biblical times, some were even regularly scheduled. The old Testament refers to Jubilee years, at half-century intervals, in which debtor slaves were to be freed and "alienated property" was to be returned to its rightful owner. See Leviticus 25:8-34.

2. In some cases -- parking tickets and library fines may be examples -- our inability to enforce rules has led to an undesirable equilibrium involving little compliance, little revenue, and many offenders outside the social contract. Better enforcement technology -- for example, computerized record-keeping or the Denver Boot -- may improve the ongoing equilibrium, reducing the need for amnesties.

3. One suspects, however, that those with draft lottery numbers just ahead of the cutoff, who would have escaped being drafted had there been fewer evaders, might have been more likely than others to oppose the draft evasion amnesty. 4. It is often difficult to distinguish profitable and realistically refinanced loans from refinancing designed to conceal bad debts. The Small Business Administration has often been accused of using rollovers to keep down 
the reported rate of default, and some of the arrangements offering new credit to developing countries that are overextended appear to be of this form. An official amnesty may provide a way to terminate such undesirable behavior. Indeed, amnesties that will officially waive or reduce some debt repayment by developing countries have been widely discussed, because it seems likely that full-value repayments will never be made.

5. Indeed, some people oppose a tax amnesty because it would seem to make evasion less of a crime. No doubt such thinking underlies the nearly universal agreement that any tax amnesty would have to be backed by a much more rigorous enforcement effort. Whereas the immigration amnesty is expected to decrease the scale of the enforcement problem dramatically, no one expects tax amnesties to reduce evasion enough to permit a substantial relaxation of enforcement. More enforcement in the tax area will simply require more resources devoted to this task.

6. The seemingly accidental and arbitrary enforcement of the Georgia law prohibiting sodomy, recently affirmed by the supreme court, struck many observers this way. The court affirmed the state's right to prohibit sexual behavior it regards as illicit even if conducted by consenting adults in their homes, but it did not comment on the differential enforcement issue. That is, no one raised the issue of the constitutionality of enforcing a law that is generally so casually enforced that apprehension would almost necessarily be accidental.

7. Both privately and publicly, we generally avoid the apparent unfairness that comes from changing our implicit contracts about enforcement. As our children grow older and more responsible, we do not enforce rules 
retroactively even if they were aware of them. We declare that prior violations are exempt -- amnestied -- but that in the future punishment will be consistent and more severe. The principle of not subjecting people to punishment more severe than what they can reasonably be said to have risked when they committed the offense is embodied in our norms for parental behavior, our common law, and our constitutional prohibition against ex post facto laws.

8. Other amnesties are also predictable. No victorious army in modern times has sought permanently to enslave the defeated population (though that was a common practice for thousands of years). In this instance, of course, the incentive effect operates in the opposite direction. Knowing that it will not be enslaved, the enemy may not fight so hard.

9. The fact that amnesties yield present benefits and future costs sets up a political incentive structure that may produce too many amnesties as administrations with limited lifespans hasten to collect the benefits, while leaving many of the costs to their successors.

10. Western justice, perhaps still in the (no more than an) eye-for-an-eye tradition, has rarely incorporated probability of detection as a significant factor in setting penalties. Partly for this reason, no doubt, penalties for tax noncompliance are quite low. The charge for late payment is 5 percent of tax due per month up to a maximum of 25 percent. The penalty for negligence is only an additional 5 percent of the tax due. Clearly our present scale of penalties is not designed for our present situation, where the probability of an audit is less than 1 percent, and even then an offense may not be provable or even identified. 
11. Undoubtedly there are even what economists call externalities -- guilt and legitimacy effects felt beyond the specific arena of the amnesty. Indeed, this may be a critical argument against an amnesty for past toxic waste dumping, despite the health gains it might offer by making future dumping less likely. The legitimacy of all society's rules would be diminished if we announced that people who have risked the public health may get off scot-free. Similarly, when we excuse past tax evaders, violators of all laws look a little less disreputable, though the externality would seem to be less severe. 12. We want tax evasion to have the moral connotation of stealing in contrast to offenses like illegal parking, for which hardly anyone suffers pangs of conscience. (A decision not to feed the meter seems merely a small wager with the parking department, of no consequence beyond the money involved.)

13. In theory individuals would multiply what they owe if caught by the probability of getting caught and choose amnesty only if they save money on average. But several kinds of conditions will make an amnesty in conjunction with a bolstered enforcement effort likely to collect more revenues than the enforcement effort alone: (1) Individuals miscalculate or fail to calculate; the publicity accompanying the amnesty may encourage them to participate. (2) Individuals are risk averse on the magnitude of fines. (3) There are nonconservative penalties such as shame or jail. (4) Amnesty allows for legitimate repentance and an escape from unfavorable self-perception.

(5) Amnesty induces enough discoverable delinquents to come forward that the population of remaining delinquents is reduced and their probability of discovery is increased. (6) Those who participate in an amnesty may provide information that implicates other evaders, thus changing the probability of 
detection.

14. Such massive gains may not be repeated. Given higher voluntary compliance, presumably the backlog of assessable delinquent taxes will shrink in the future.

15. The slower growth of revenues in these states may have created particularly severe pressure to find new revenues or improve the ir tax compliance.

16. Proceeding state by state, we first measured the difference between each state's growth in revenues and the national average growth for the preamnesty period. Using 1983 observed revenues, we then projected 1984 revenues in the absence of amnesty by assuming that the state's revenue growth rate would have continued to differ from the national average by the same amount as in the preamnesty period. We then compared the estimated revenues without amnesty to the revenues actually observed with the amnesty programs in place. This amounts to fitting a fixed-effects model for state revenue growth rates, with each state permitted to have growth differing from the national average and to have its own "amnesty" effect. In particular, it assumes no regression toward the mean. We place little reliance on the individual state results, preferring instead to examine the aggregated results.

17. We obtain a range of estimates because there are various plausible ways to estimate revenues in the amnesty states under the hypothetical scenario "without amnesty." Using different base periods to measure state differentials from the national average, projecting 1985 revenues one year forward from 1984 rather than two years forward from 1983, and other sma 11 changes in assumptions result in minor variations in the results. We are 
certain that other approaches to making these projections would lead to different results and that alternative explanations having nothing to do with amnesty could be advanced. Nonetheless, our results do not seem implausible, and they are robust against small variations in the assumptions underlying the calculations presented here.

18. This counts revenues and tax amnesty gains for 1984 for the 1984 amnesty states only; revenues and gains for 1985 are counted for both 1984 and 1985 amnesty states.

19. Allen H. Lerman, "Tax Amnesty: The Federal Perspective," National Tax Journal, Vol. 39, No. 3, pp. 325-332, 1986.

20. See, for example, Frank Malanga, "The Relationship Between IRS Enforcement and Tax Yield," National Tax Journal, Vol. 39, No. 3, pp. 333-337, 1986.

21. To maximize net revenues raised, enforcement would be pushed until the last dollar yielded a dollar of revenue, since taxes paid are a transfer, whereas enforcement expenditures represent real resource costs. The efficiency argument for greater enforcement is that it leads to lower overall tax rates, thus reducing adverse consequences for incentives. Many critics, of course, are more interested in the equity effects of enforcement, its ability to distribute more equally the tax burden imposed on individuals with similar incomes.

22. This fact is most startling when we consider that virtually all income taxed by the states is taxed by the federal government as well, and that there is a matching program for tax compliance between the two levels.

23. Lerman, op. cit., at $\mathrm{fn} 3$. 
24. Massachusetts Department of Revenue, "The Massachusetts Amnesty Program: A Statistical Synopsis," Mimeo: June 1986. The remaining 39 percent took advantage of amnesty to pay debts already on tax collectors' books as accounts receivable without penalties.

25. Indeed, some would argue the trend at the federal level has been in the other direction. The proportion of taxpayers now audited is less than half what it was 20 years ago. The IRS argues that the lower audit rate is more than offset through better targeting, electronic record matching, and other more effective modern information-processing approaches.

26. U.S. Department of Treasury, Internal Revenue Service, Income Tax Compliance Research: Estimates for 1973-1981, Washington, D.C.: July 1983. 27. Lerman presents a similar argument. Since he concentrates on amnesty alone, however, his analys is answers a different question about the amount of revenue to be gained from underreporting and overdeducting on previously filed forms. He argues that amnesty alone will do little to bring forward those who have consciously evaded their liabilities. Since we are analyzing a combined package of tougher enforcement and amnesty, the \$70 billion of "ordinary" tax-shaving is a potentially considerable source of revenue. See Lerman, op. cit., pp. 329-331.

28. Several steps could be taken to make amnesties more likely to work. Many forms of tax evasion involve more than one person; society might want to advertise that if you have ever colluded to avoid taxes you had better take advantage of amnesty because your partners might do so, and we will chase down others involved in schemes that come to light under amnesty. Even snitching could be given greater rewards. 
29. Ira Jackson, speech to National Tax Association -- Tax Institute of America, May 19, 1986, p. 11. Jackson discusses the figures cited above on the frequency with which the IRS abates penalties.

30. The IRS has not been run as a profit center and does not directly retain any of the revenue it collects. Tax reform proposals included a provision to permit the IRS to keep a fraction of its enforcement collections, but the spectre of IRS agents overeager to collect from hapless taxpayers led to the rejection of this idea. 


\section{Bibliography}

Business Week, "Coming clean: Tax Amnesty May Be Heading for Washington," March 10, 1986, p. 31 .

Jackson, Ira A., "Amnesty and Creative Tax Administration," National Tax Journal Vol. XXXIX, No. 3, pp. 317-324, 1986.

Lerman, Allen H., "Tax Amnesty: The Federal Perspective," National Tax Journal Vol. XXXIX, No. 3, pp. 325-332, 1986.

Malanga, Frank, "The Relationship Between IRS Enforcement and Tax Yield," National Tax Journal Vol. XXXIX, No. 3, pp. 333-337, 1986.

Massachusetts Department of Revenue, "Fair and Firm Federal Tax Administration," Mimeo, May 1986.

Massachusetts Department of Revenue, "Massachusetts Amnesty Program: A Statistical Synopsis," Mimeo, June 1986.

Tax Foundation, "Excises, Amnesty, and Fiscal Foibles," Mimeo, Washington, D.C., April 1986.

U.S. Bureau of the Census, State Tax Collections, various years.

U.S. Department of Treasury, Internal Revenue Service, Income Tax Compliance Research: Estimates for 1973-1981, Washington, D.C.: July 1983. 